Article

\title{
Improvement of Performances of the Gypsum-Cement Fiber Reinforced Composite (GCFRC)
}

\author{
Natalia Chernysheva ${ }^{1}$, Valery Lesovik ${ }^{1}$, Roman Fediuk ${ }^{2, *}$ and Nikolai Vatin ${ }^{3}$ \\ 1 Department of Building Materials, Products and Structures, Belgorod State Technological University Named \\ after V.G.Shoukhov, 46, Kostiukova Str., 308012 Belgorod, Russia; chernysheva56@rambler.ru (N.C.); \\ naukavs@mail.ru (V.L.) \\ 2 School of Engineering, Far Eastern Federal University, 8, Sukhanova Str., 690950 Vladivostok, Russia \\ 3 Higher School of Industrial, Civil and Road Construction, Peter the Great St. Petersburg Polytechnic \\ University, 195251 St. Petersburg, Russia; vatin@mail.ru \\ * Correspondence: fedyuk.rs@dvfu.ru
}

Received: 3 August 2020; Accepted: 26 August 2020; Published: 31 August 2020

\begin{abstract}
The novelty of this paper lies in the identification of the scientific patterns of the influence of thermal power plant waste (TPPW) on the hydration mechanism and the structure of the gypsum-cement binder (GCB). The classification of raw materials for the production of GCB has been developed taking into account the genesis, which contributes to the prediction of the properties of composites. The features of the hydration phase formation and hardening of GCB have been studied taking into account the chemical, structural and morphological features of fly ash and slag. In addition, the microstructural, morphological, and thermal properties of the cured binders at a 28 day cure were determined. For the first time, scientific data on the properties of gypsum-cement fiber-reinforced composite using TPPW and microfiber have been obtained. The results show that the synergistic effect of gypsum-cement binder, TPPW, and polyamide or basalt microfiber improves the physicomechanical properties of a 28 day cured binder: compressive strength of $20 \mathrm{MPa}$, flexural strength of $8.9 \mathrm{MPa}$, and softening coefficient 0.87 .
\end{abstract}

Keywords: gypsum; cement; fly ash; slag; fiber

\section{Introduction}

One of the most important problems of our time is the creation of comfortable conditions for human existence in regard to the use of building structures and materials [1]. At the same time, it is necessary to reduce the energy intensity of the production of composites, expand the range of building materials and effective technologies for their production, taking into account the genesis of raw materials and the sustainability of the "man-material-environment" system [2,3]. Current trends in the development of building materials science are associated with the transition to the creation of multicomponent, multilayer, multilevel composite materials with a given set of properties, their structural and functional organization $[4,5]$. This ensures their behavior, that they are adapted to variable environmental factors throughout the life of the operation, but also, at least, the preservation or improvement of the quality of the environment $[6,7]$.

Papers in the field of gypsum binders, materials, and products, as well as favorable environmental, technical, and economic aspects of the production and use of these materials indicate that these are all prerequisites for widespread use in construction [8-11]. In this regard, the development of effective quick-hardening building composites, obtained using new types of available raw materials with improved performance characteristics, is required $[12,13]$. These requirements are met by water-resistant 
and frost-resistant gypsum-cement composites, which can reduce the deficit of wall materials, replace energy-intensive cement concrete and shorten the construction time of buildings [14-16]. The use of these materials in construction significantly reduces the negative impact on the environment compared to the traditionally used Portland cement (Table 1).

Table 1. The environmental aspect of the production of mineral binders [17-19].

\begin{tabular}{|c|c|c|c|c|c|c|c|}
\hline \multirow{3}{*}{$\begin{array}{l}\text { Type of } \\
\text { Binder }\end{array}$} & \multirow{3}{*}{$\begin{array}{l}\text { Annual Production in } \\
\text { the World, Million Tons }\end{array}$} & \multicolumn{2}{|c|}{ Energy Intensity } & \multicolumn{4}{|c|}{ Emissions } \\
\hline & & \multirow{2}{*}{$\begin{array}{l}\text { Production of } 1 \mathrm{t} \text {, } \\
\text { kg Fuel Equivalent }\end{array}$} & \multirow{2}{*}{$\begin{array}{l}\text { Total, Mill. t } \\
\text { Fuel Equivalent }\end{array}$} & \multicolumn{2}{|c|}{$\mathrm{CO}_{2}$} & \multicolumn{2}{|c|}{ Dust } \\
\hline & & & & $g / t$ & $\begin{array}{l}\text { Total, } \\
\text { Mill. t }\end{array}$ & $\mathrm{g} / \mathrm{t}$ & $\begin{array}{l}\text { Total, } \\
\text { Mill. } t\end{array}$ \\
\hline Cement & 3700 & 150 & 555 & 50 & 2159 & 21 & 53.34 \\
\hline Lime & 340 & 204 & 69.36 & 28 & 151 & 5 & 1.43 \\
\hline Gypsum & 152 & 47 & 7.144 & - & - & - & - \\
\hline
\end{tabular}

Many research papers have been devoted to solving the problem of managing the structure formation of gypsum and cement materials [20-23]. At the same time, there are much fewer papers devoted to gypsum-cement binders (GCB) with various additives [24]. In Figure 1, an attempt is made to conduct a generalized analysis of natural and technogenic raw materials that can be used for the production of gypsum-cement binders.

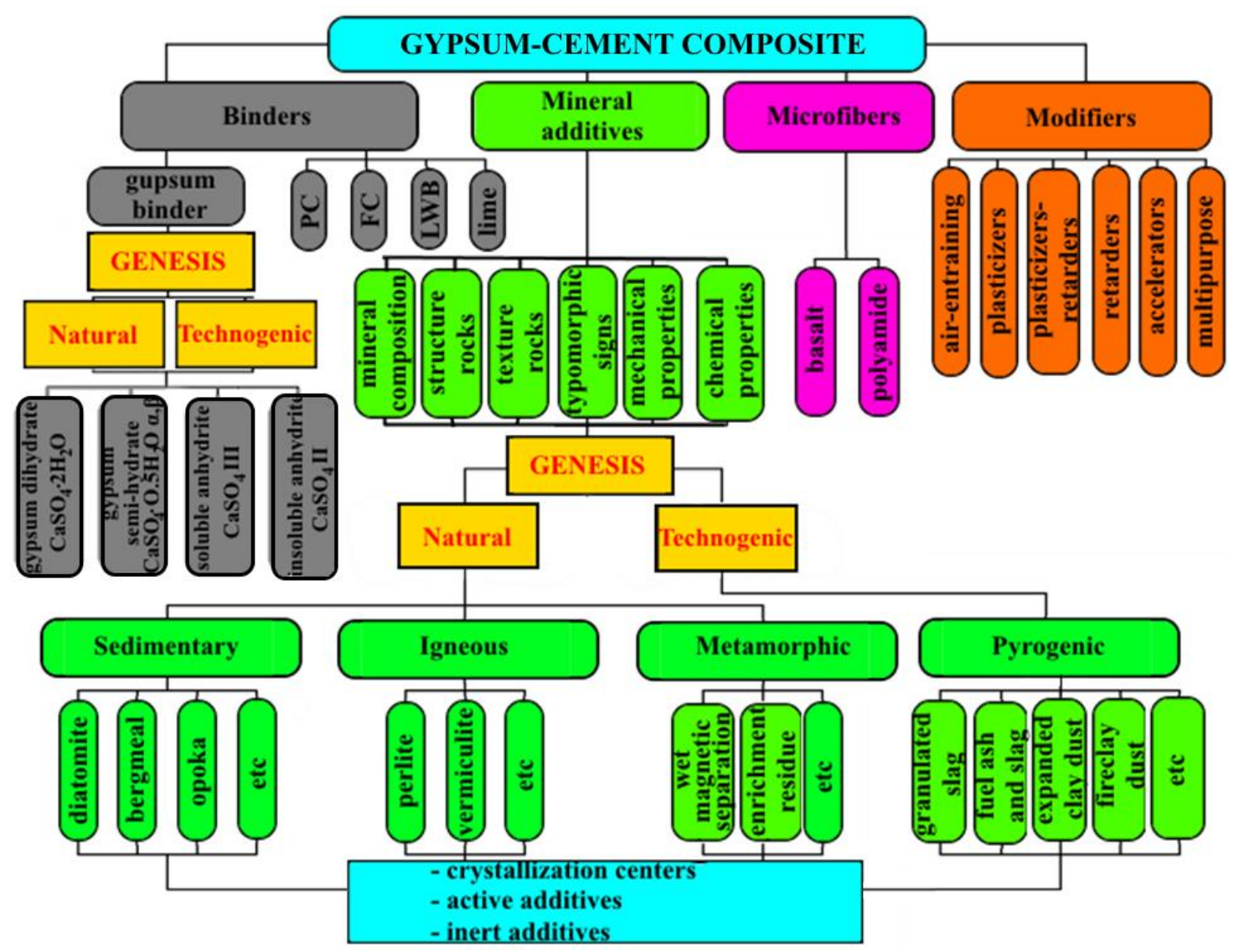

Figure 1. Classification of raw materials for the production of gypsum-cement binders (GCB) [25-28].

As seen from Figure 1, the conditions for the formation of gypsum binders and mineral additives are the basis for their division into classes. According to this criterion, the materials were divided into natural and man-made. There are three classes of mineral additives, such as crystallization centers, active mineral additives and excipients. The source of the formation of mineral additives are various rocks of sedimentary (diatomite, trepel, opoka), volcanic (tuff, perlite, vermiculite) and metamorphic 
genesis (quartzite sandstone, ferruginous quartzites), as well as mechanogenic and pyrogenic origin (concrete waste, expanded clay dust, chamotte dust, ash and slag waste).

At the same time, the utilization of industrial waste is a priority for scientists of various fields of knowledge $[29,30]$. Therefore, the study of the influence of fly ash and hydrodynamic slag from a thermal power plant on the structure formation of a gypsum-cement system is an urgent task.

The second important task that is solved in this article is to increase the strength characteristics of gypsum cement composites using micro-reinforcing fibers. It is known that the use of various fibers, both in cement and in the gypsum matrix, helps to reduce shrinkage cracks by $50-90 \%$ [31,32]. Obviously, the fiber content in the gypsum-cement fiber-reinforced composite (GCFRC) will increase its frost resistance and durability characteristics to the level of composites with air-entraining additives.

Thus, the goal of the article is to improve the characteristics of the gypsum-cement fiber reinforced composite using various wastes of the thermal power station and micro-reinforcing fibers.

\section{Materials and Methods}

\subsection{Characteristics of the Raw Materials Used}

Gypsum $\beta$-modifications of the grade G-5B II (Belgorod, Russia) was used as a component of the gypsum-cement binder (Table 2).

Table 2. Characteristics of the gypsum used.

\begin{tabular}{cc}
\hline Bulk density, $\mathrm{kg} / \mathrm{m}^{3}$ & 650 \\
Fineness as residue on the sieve of $0.2 \mathrm{~mm}, \%$ & 10 \\
\hline Standard consistency & 0.48 \\
\hline Setting time, min-sec \\
start \\
end & $3-00$ \\
\hline Flexural strength, MPa & $12-00$ \\
\hline Compressive strength, MPa & 2.4 \\
dry to constant weight & 6.0 \\
water saturated & 11.6 \\
Softening coefficient & 5.3 \\
\hline
\end{tabular}

Portland cement CEM I $42.5 \mathrm{~N}$ (Belgorodsky cement, Belgorod, Russia) with a bulk density of $1150 \mathrm{~kg} / \mathrm{m}^{3}$ was used as a binder material. Fly ash (FA) and slag of the Grozny thermal power plant (TPP) (Grozny, Russia) were used as silica-containing components. The bulk density of fly ash and slag was 900 and $1100 \mathrm{~kg} / \mathrm{m}^{3}$, respectively. According to the XRD data (Figure 2), the fly ash of the Grozny TPP consists of two modifications of quartz $(\mathrm{d}=3.403,3.247 \mathrm{~A})$, magnetite $\mathrm{Fe}_{3} \mathrm{O}_{4}(\mathrm{~d}=2.987$, $2.600,2.119,1.493 \mathrm{~A})$, calcite $\mathrm{CaCO}_{3}(\mathrm{~d}=3.081 \mathrm{~A})$, calcium-iron silicate $\mathrm{CaFeSi}_{2} \mathrm{O}_{6}$. The excess of the background in the region of $20-40^{\circ}$ is mainly due to the high iron content.

Mostly (up to $95 \%$ ) glass phase is present in the slag. The crystalline phase is represented by albite, NaAl-silicates and Al-silicates, several different modifications of quartz, which differ from the natural modifications by the crystal lattice parameters $(\mathrm{d}=4.327,4.106,3.386,3.283,2.477,2.351$, $2.255,2.140,1.990,1.788,1.681,1.660,1.549,1.458 \mathrm{~A})$, which is associated with its technogenic origin. The XRD pattern contains peaks of two fairly strong varieties of silicate (albite and anorthoclase $\mathrm{K}, \mathrm{Na}$ $\left(\mathrm{AlSi}_{3} \mathrm{O}_{8}\right)(\mathrm{d}=3.888,3.283,3.23,2.983 \mathrm{~A})$, except in addition, there are peaks of mica-hydronosodium aluminosilicates $(\mathrm{d}=3.527)$, magnetite $\mathrm{Fe}_{3} \mathrm{O}_{4}(\mathrm{~d}=3.00,2.55 \mathrm{~A})$ and calcite $\mathrm{CaCO}_{3}(\mathrm{~d}=3.03,3.065 \mathrm{~A})$. In the range of $31-32^{\circ}$, the interplanar spacings of sodium aluminum silicates are broadened $\left(\mathrm{AlSi}_{3} \mathrm{O}_{8}\right)$, and there is also a significant background increase under these interplanar distances $(d=3.383-3.23 \mathrm{~A})$, which indicates the partial presence of their amorphized state ( $\mathrm{a}$ in Figure 2). As a result of calculations based on the maximum intensity of interplanar distances, of minerals $\mathrm{SiO}_{2}$ and $\mathrm{K}, \mathrm{Na}\left(\mathrm{AlSi}_{3} \mathrm{O}_{8}\right)$ and the 
background value, it was found that the content of crystalline $\mathrm{SiO}_{2}$ is $56.9 \%$, amorphous $\mathrm{SiO}_{2}-3.7 \%$, amorphous $\mathrm{K}, \mathrm{Na}\left(\mathrm{AlSi}_{3} \mathrm{O}_{8}\right)-39.4 \%$.

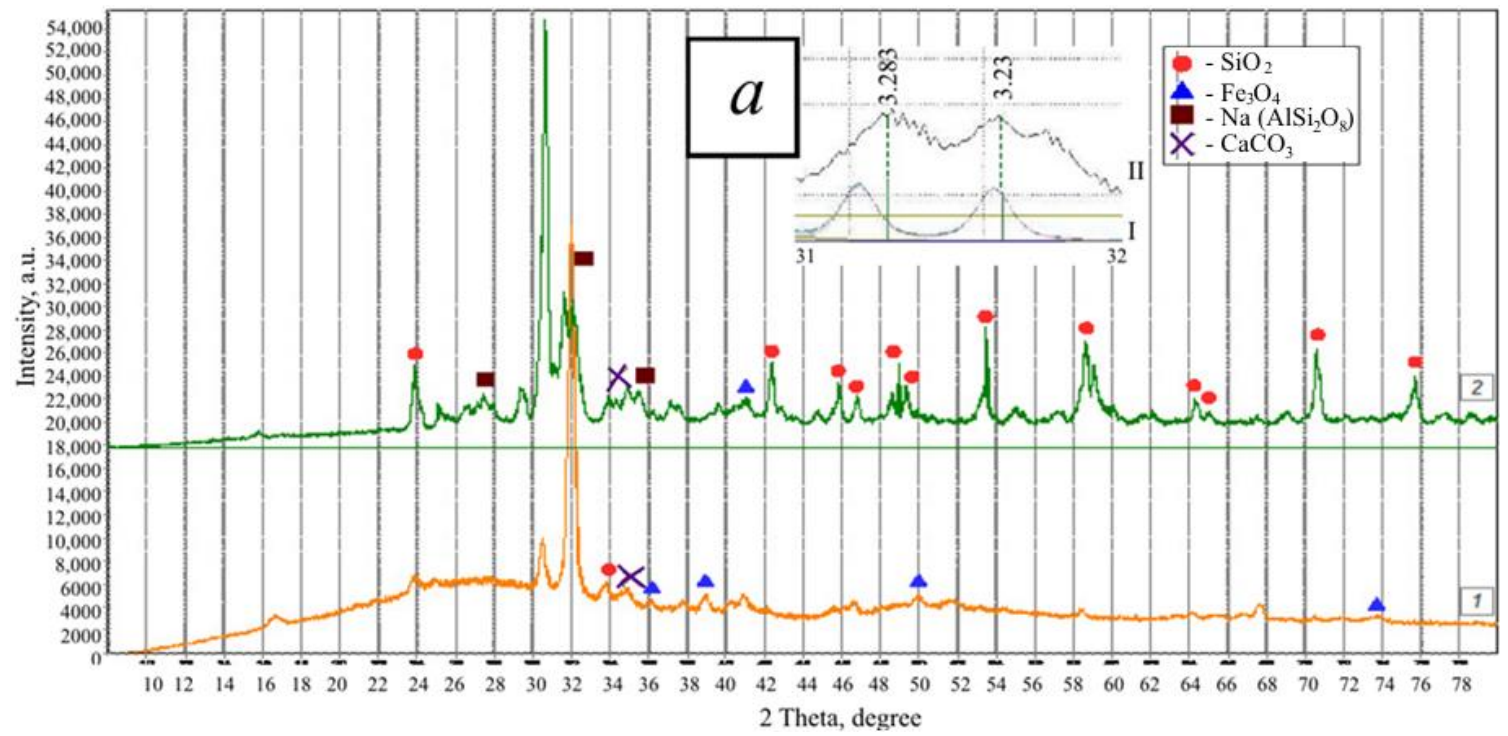

Figure 2. XRD patterns of fly ash (1) and slag (2) of the Grozny TPP, $a$-comparison of the interplanar distances of $\mathrm{Na}\left(\mathrm{AlSi}_{3} \mathrm{O}_{8}\right)$ in nature (I) and in the slag (II).

Thus, both in fly ash and in slag, a large number of X-ray amorphous phases are noted. This characterizes the pozzolanic activity necessary for the binding of calcium hydroxide released during the hydration of clinker minerals into secondary hydrosilicates of calcium. The slag particles are layered and consist of dense glassy particles of various sizes of cubic or rounded shape (Figure 3a).

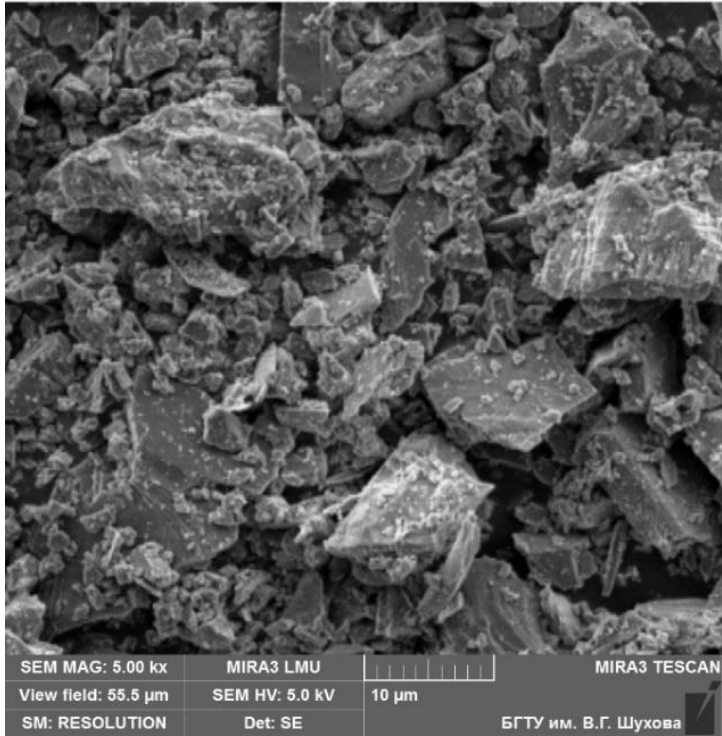

(a)

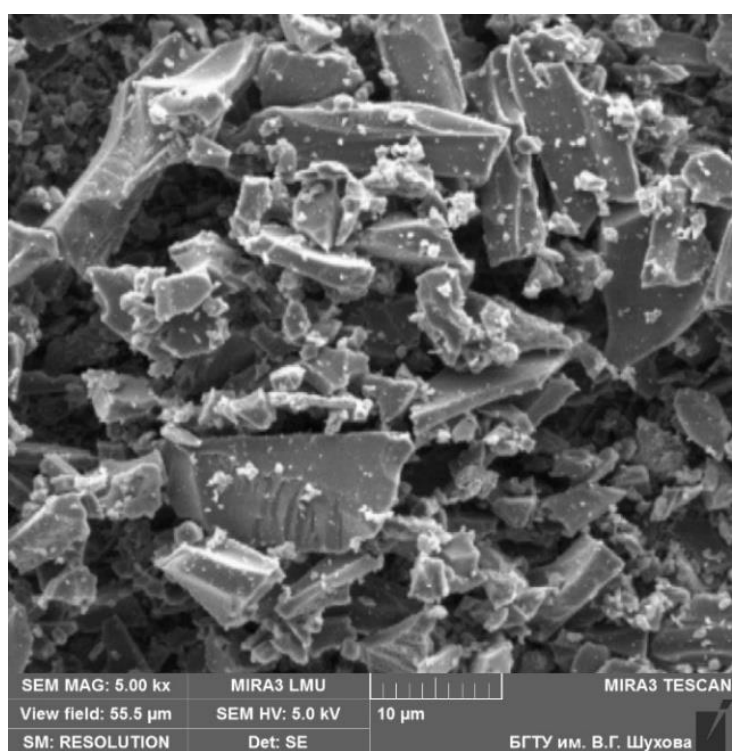

(b)

Figure 3. SEM images: (a) slag, (b) fly ash.

Most of the ash consists of porous glassy particles of various sizes, which have a lamellar, irregular, and angular shape (Figure 3b). Porous, relatively large particles with a concave surface are observed, as well as small particles of a flaky structure. The chemical compositions of the used Portland cement, fly ash, and slag are listed in Table 3. 
Table 3. Technical characteristics of the micro-reinforcing fibers.

\begin{tabular}{cccccccc}
\hline Chemical Composition & $\mathbf{C a O}$ & $\mathbf{S i O}_{\mathbf{2}}$ & $\mathbf{A l}_{\mathbf{2}} \mathbf{O}_{\mathbf{3}}$ & $\mathbf{F e}_{\mathbf{2}} \mathbf{O}_{\mathbf{3}}$ & $\mathbf{M g O}$ & $\mathbf{S O}_{\mathbf{3}}$ & Alkalis \\
\hline CEM I, \% & 65.5 & 21.8 & 4.9 & 4.0 & 1.2 & - & 0.6 \\
Fly ash, \% & 31.4 & 32.4 & 5.6 & 31.4 & 2.3 & 1.3 & 2.9 \\
Slag, \% & 2.6 & 67.5 & 15.0 & 2.6 & 0.5 & 0.2 & 7.8 \\
\hline
\end{tabular}

To improve the rheology, the superplasticizer SP Melment F10 (BASF, Ludwigshafen, Germany) with a bulk density of $550 \mathrm{~kg} / \mathrm{m}^{3}$ was used. It is optimized to plasticize and reduce water consumption for cement-gypsum mixtures. High modulus basalt and low modulus polyamide fibers were used for micro reinforcing (Table 4). Basalt and polyamide fibers have a density of 2800 and $1100 \mathrm{~kg} / \mathrm{m}^{3}$, respectively. They are chopped thin fibers with a length of about $10 \mathrm{~mm}$ and a diameter of 30-100 $\mu \mathrm{m}$.

Table 4. Technical characteristics of the micro-reinforcing fibers.

\begin{tabular}{ccccc}
\hline Fiber & Density, $\mathbf{~ k g} / \mathbf{m}^{\mathbf{3}}$ & Tensile Strength, MPa & Elastic Modulus, MPa & Elongation at Break, \% \\
\hline Polyamide & 900 & $720-750$ & $1900-2000$ & $24-25$ \\
Basalt & $2600-2700$ & 1600 & $8000-11,000$ & $1.4-3.6$ \\
\hline
\end{tabular}

\subsection{Laboratory Equipment and Research Methods}

The ARL X'TRA device (Thermo Fisher Scientific, Waltham, MA, USA) was used for the X-ray diffraction analysis. The microstructure of raw materials and synthesized composites were studied using a Tescan Mira 3 electron microscope (Brno, Czech), which allows not only to obtain SEM images, but also to carry out $X$-ray fluorescence analysis.

Studies of the composition of hydration products by differential-thermal analysis (DTA) at the age of 28 days were carried out on by the Q600 synchronous thermal analyzer (SDT, Waltham, MA, USA).

The binder components were ground in a LSM ball mill (Moscow, Russia). The specific surface area of the powders was determined on a PSH-2 device (Moscow, Russia). The BET (Brunauer Emmett Teller) area was determined on a Sorbi-M device(Moscow, Russia). Particle size distribution was performed on a MicroSizer 201 device (Moscow, Russia).

The determination of a standard consistency and setting time of the gypsum-cement paste was carried out using the Vik device (Moscow, Russia).

The slump flow of the paste of standard consistency should correspond to $120 \pm 5 \mathrm{~mm}$.

To study the physicomechanical characteristics of the obtained gypsum-cement binders, 6 specimens were molded for each composition. The determination of the compressive strength of the GCB was carried out on sample cubes measuring $100 \times 100 \times 100 \mathrm{~mm}^{3}$. Upon reaching the age of 2, 7, and 28 days, as well as after drying to constant weight, the specimens were tested according to EN 12,390-3:2009. Flexural strength of the GCB was determined on beams with a size of $40 \times 40 \times 160 \mathrm{~mm}^{3}$ after 7 and 28 days following EN 1015-11.

The softening coefficient was determined as the ratio of the compressive strength of water-saturated specimens to the compressive strength of dried specimens. In other words, a softening coefficient is actually a coefficient of water resistance, which for gypsum materials is one of the most important indicators of durability.

\subsection{Mix Design}

The preparation of mixes included 3 stages: crushing and drying of a mineral additive (1), mixing of the mineral additive with Portland cement and superplasticizer (2) and the addition of a gypsum binder with short-term grinding of the mix (3). The proportions of the mixtures are gypsum $-70 \%$, cement-15\%, mineral additive-15\%. The amount of superplasticizer $1 \%$ by weight of the mix. The amount of water was selected for each composition individually, taking into account the achievement of a standard consistency. 
In terms of calcium oxide, the concentration of calcium hydroxide in the liquid phase of the solidifying suspension, regulated by the Russian standard TU 21-31-62-89, on days 5 and 7, respectively, should not exceed 1.1 and $0.85 \mathrm{~g} / \mathrm{L}$. For this purpose, two batches of preparations were prepared from 12 samples (6 samples each), with different amounts of mineral additives (Table 5).

Table 5. Compositions of preparations for determining the effect of mineral additives on the concentration of $\mathrm{CaO}$ in aqueous gypsum-cement suspensions.

\begin{tabular}{ccccc}
\hline \multirow{2}{*}{ Sample } & \multicolumn{4}{c}{ Amount of Materials for Creating of Preparations, g } \\
\cline { 2 - 5 } & Gypsum & Portland Cement & Mineral Additive & Distilled Water \\
\hline 1 & 4 & 2.5 & 0.625 & 100 \\
2 & 4 & 2.5 & 1.25 & 100 \\
3 & 4 & 2.5 & 2.5 & 100 \\
4 & 4 & 2.5 & 3.75 & 100 \\
5 & 4 & 2.5 & 5 & 100 \\
6 & 4 & 2.5 & 6.25 & 100 \\
\hline
\end{tabular}

The filtered solution was titrated with $0.1 \mathrm{~N}$ hydrochloric acid solution in the presence of phenolphthalein. The concentration of $\mathrm{CaO}(\mathrm{g} / \mathrm{L})$ was determined by the formula:

$$
\mathrm{CaO}=768 \cdot A \cdot \mathrm{T} / \mathrm{B}
$$

where $A$ is the amount of hydrochloric acid used for titration, $\mathrm{mL} ; T$ is the titer of hydrochloric acid ( $\mathrm{HCl}$ content, $\mathrm{g} / \mathrm{mL}) ; B$ is the amount of the test solution, $\mathrm{mL}$.

As a result of the studies carried out, the concentration of $\mathrm{CaO}$ in the solutions was established:

- $\quad$ with fly ash (GCB-FA): after 5 days $0.75-1.1 \mathrm{~g} / \mathrm{L}$, after 7 days $0.82-0.85 \mathrm{~g} / \mathrm{L}$ with a cement/additive ratio of $1: 1-1: 1.5$.

- $\quad$ with slag (GCB-S): after 5 days $1.04-1.1 \mathrm{~g} / \mathrm{L}$, after 7 days $0.64-0.85 \mathrm{~g} / \mathrm{L}$ with a cement/additive ratio of $1: 1-1: 1.5$.

In the technology of preparing gypsum-cement composites, uniform distribution of fiber is difficult. Therefore, fiber was introduced to the dry mixture of GCB, and then water with the superplasticizer was added, followed by continuous stirring for $5 \mathrm{~min}$ until a homogeneous mass was obtained.

\subsection{Measurement Error}

The number of specimens for each tests was 6, while the coefficient of variation of the results did not exceed $5 \%$, and the standard deviation was within 0.95 , which ensured the reliability of the results obtained.

\section{Results and Discussion}

\subsection{Mechanical Activation of the GCB Components}

Figure 4 shows the particle sizes distribution of slag and fly ash with a specific surface area of 470 and $690 \mathrm{~m}^{2} / \mathrm{kg}$, respectively. About $90 \%$ of fly ash particles are limited to $18.15-201 \mu \mathrm{m}$ fractions, and slag particles are limited to $1.1-16.35 \mu \mathrm{m}$ fractions.

Microporosity depends on the cooling rate of the particles of the feedstock, rapid cooling contributes to this process. Accordingly, in the fly ash compared with the slag revealed a greater number of pores and a large specific surface, as listed in Table 6. 


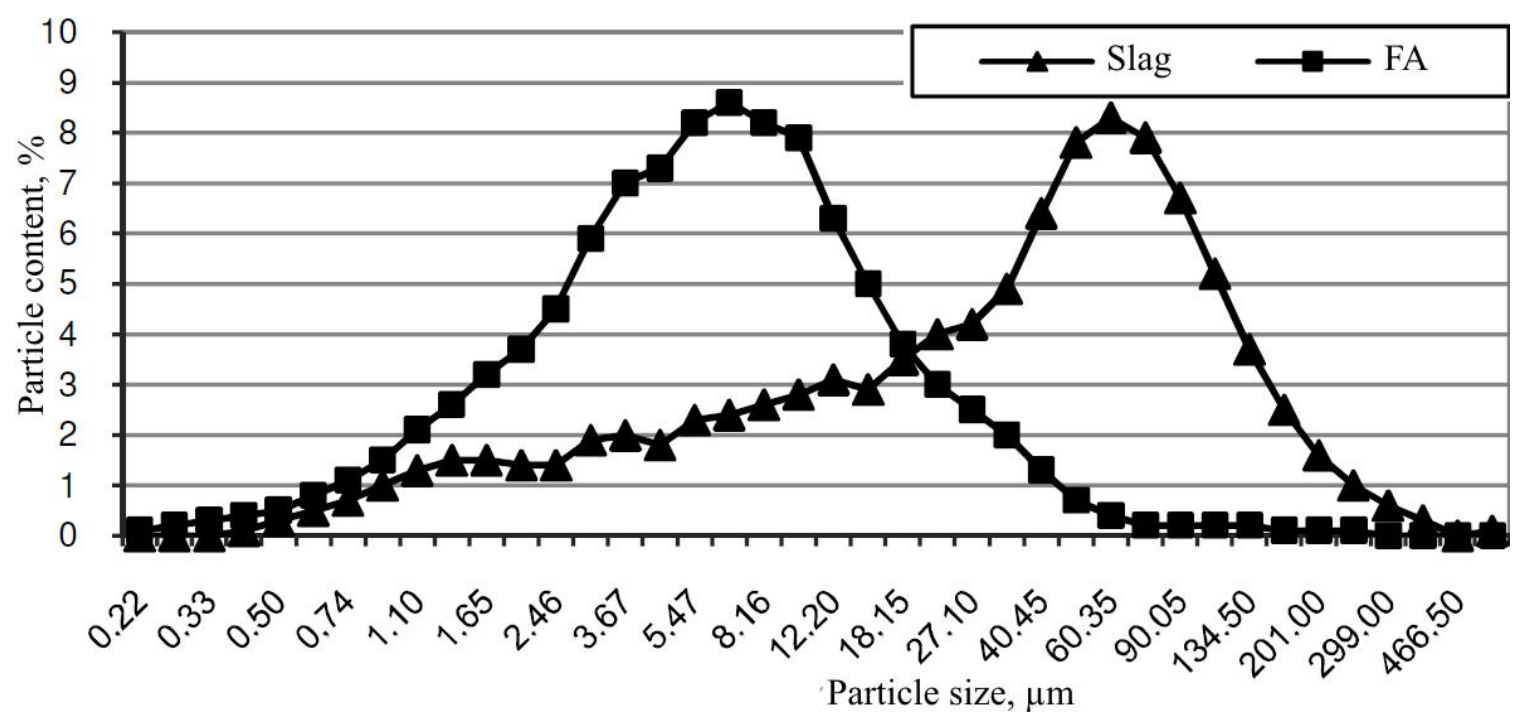

Figure 4. Fly ash (FA) and slag Particle size distribution.

Table 6. Properties of finely ground fly ash and slag.

\begin{tabular}{ccc}
\hline Properties & Fly Ash & Slag \\
\hline Specific surface area determined by a PSH-2 device, $\mathrm{m}^{2} / \mathrm{kg}$ & 690 & 470 \\
BET area determined by a Sorbi-M device, $\mathrm{m}^{2} / \mathrm{g}$ & 72.00 & 1.64 \\
Pore volume with radius less than $19.4 \mathrm{~nm}, \mathrm{~cm}^{2} / \mathrm{g}$ & 0.018 & 0.003 \\
\hline
\end{tabular}

From Table 6, the specific surface of mineral additives determined on the PSH-2 device is not identical to the BET area. This is due to the fact that the microporosity of particles can be not only closed, but also open. The high specific surface of mineral additives indicates their increased reactivity.

Figure 5 shows the particle size distribution of the GCB.

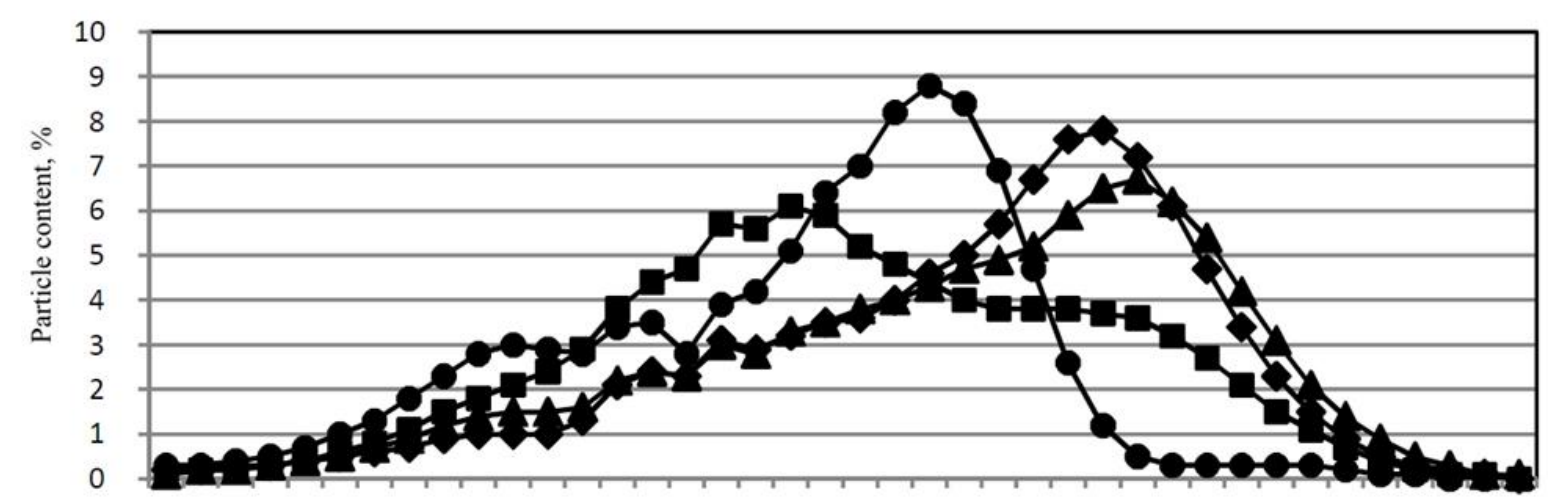

춖

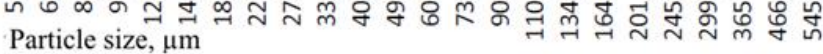

$\longrightarrow$ CEM I $\longrightarrow$ GCB-FA $\longrightarrow$ GCB-S $\longrightarrow$ gypsum

Figure 5. Particle size distribution of the GCB.

\subsection{Microstructure of the GCB}

Table 7 lists the composition of the products of hydration of the GCB at the age of 28 days, where fly ash is used as a mineral additive. 
Table 7. The composition of the hydration products of the gypsum-cement binder- fly ash (GCB-FA) at microprobe points.

\begin{tabular}{cccccc}
\hline \multirow{2}{*}{ Elements } & \multicolumn{5}{c}{ Content of Elements, wt.\% at Microprobe Points } \\
\cline { 2 - 6 } & $\mathbf{1}$ & $\mathbf{2}$ & $\mathbf{3}$ & $\mathbf{4}$ & $\mathbf{5}$ \\
\hline $\mathrm{C}$ & 79.8 & 30.8 & 47.0 & 16.2 & 83.3 \\
$\mathrm{O}$ & 9.8 & 42.8 & 32.8 & 44.1 & 13.9 \\
$\mathrm{Si}$ & 1.4 & 3.8 & 3.2 & 5.5 & 0.7 \\
$\mathrm{Ca}$ & 6.7 & 20.2 & 12.2 & 22.2 & 2.2 \\
$\mathrm{Fe}$ & 0.6 & 0.2 & 2.3 & 5.2 & - \\
$\mathrm{Mg}$ & 1.1 & 0.1 & - & 1.7 & - \\
$\mathrm{S}$ & 0.7 & 0.8 & 0.7 & 2.1 & - \\
$\mathrm{Na}$ & - & 0.1 & - & - & - \\
$\mathrm{K}$ & 0.1 & 0.3 & 0.5 & 0.5 & - \\
$\mathrm{Al}$ & 0.7 & 0.7 & 1.5 & 4.0 & - \\
\hline
\end{tabular}

At the age of two days, a loose structure with a significant number of pores is observed (Figure 6a). At the same time, there are both large pores and small pores between the crystals of new growths. Further, the spaces between the crystals of calcium sulfate dihydrate are filled with ultrafine particles of Portland cement and an active mineral additive, as well as the smallest particles of new growths (Figure 6b). This contributes to an increase in contacts between crystals. After 28 days, under conditions of a solution saturated with lime, calcium hydrosilicates acquire the morphology of dendrite-like formations that create a densified shell around gypsum particles (Figure 6c). When the shell becomes sufficiently dense, the particles are combined into a continuous structure. Due to the hydrosilicates of this morphology, the hardened binder gains strength, its density, water resistance, and durability increase.

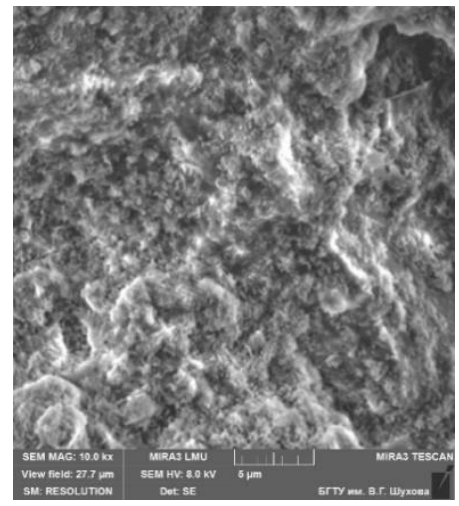

(a)

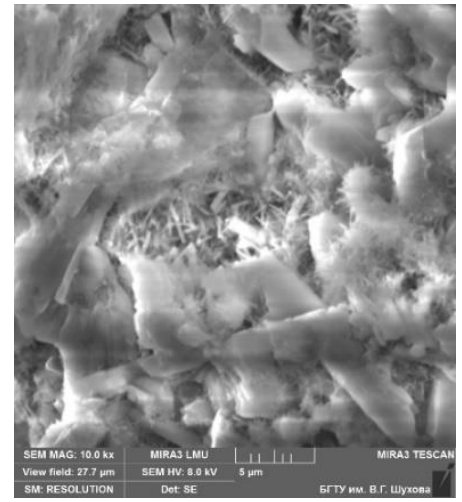

(b)

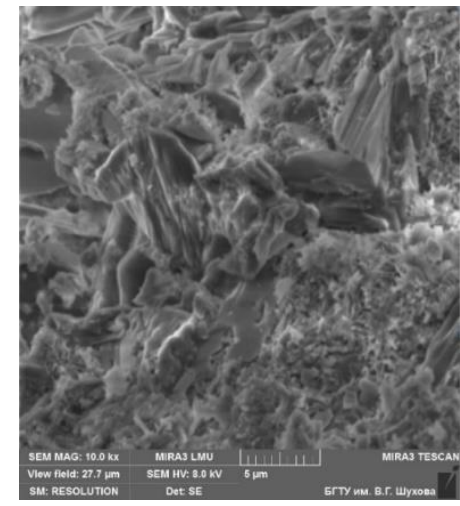

(c)

Figure 6. The microstructure of the hardened GCB-FA. at the age of 2 (a), 7 (b) and 28 (c) days.

Clinker minerals with fly ash reacted more intensely than in the system with slag. A greater amount of $\mathrm{Ca}(\mathrm{OH})_{2}(\mathrm{~d}=4.9 \mathrm{~A})$ and $\mathrm{CaCO}_{3}(\mathrm{~d}=2.088,1.89 \mathrm{~A})$ are observed. However, these reflections are not visible on XRD patterns, as they overlap with gypsum reflections (Figure 7).

The XRD pattern contains peaks of two strong varieties of silicates (albite and anorthoclase $\mathrm{K}, \mathrm{Na}$ $\left(\mathrm{AlSi}_{3} \mathrm{O}_{8}\right)(\mathrm{d}=3.888,3.283,3.23,2.983 \mathrm{~A})$.

Figure 8 shows the results of the differential thermal analysis of the developed GCB-FA at the age of 28 days. The endothermic effect at temperatures of $160-220^{\circ} \mathrm{C}$ is caused by the dehydration of gypsum $\mathrm{CaSO}_{4} \cdot 2 \mathrm{H}_{2} \mathrm{O}$. The following effect at a temperature of $560{ }^{\circ} \mathrm{C}$ is characterized by the decomposition of portlandite. The last endothermic effect at temperatures of $890-910{ }^{\circ} \mathrm{C}$ is caused by the dissociation of calcium carbonate $\mathrm{CaCO}_{3}$. Two exothermic effects are also observed: at $500{ }^{\circ} \mathrm{C}, \mathrm{Fe}^{+2}$ is oxidized to $\mathrm{Fe}^{+3}$, and at $780-820^{\circ} \mathrm{C}, \mathrm{CSH}$ (B) decomposes. 


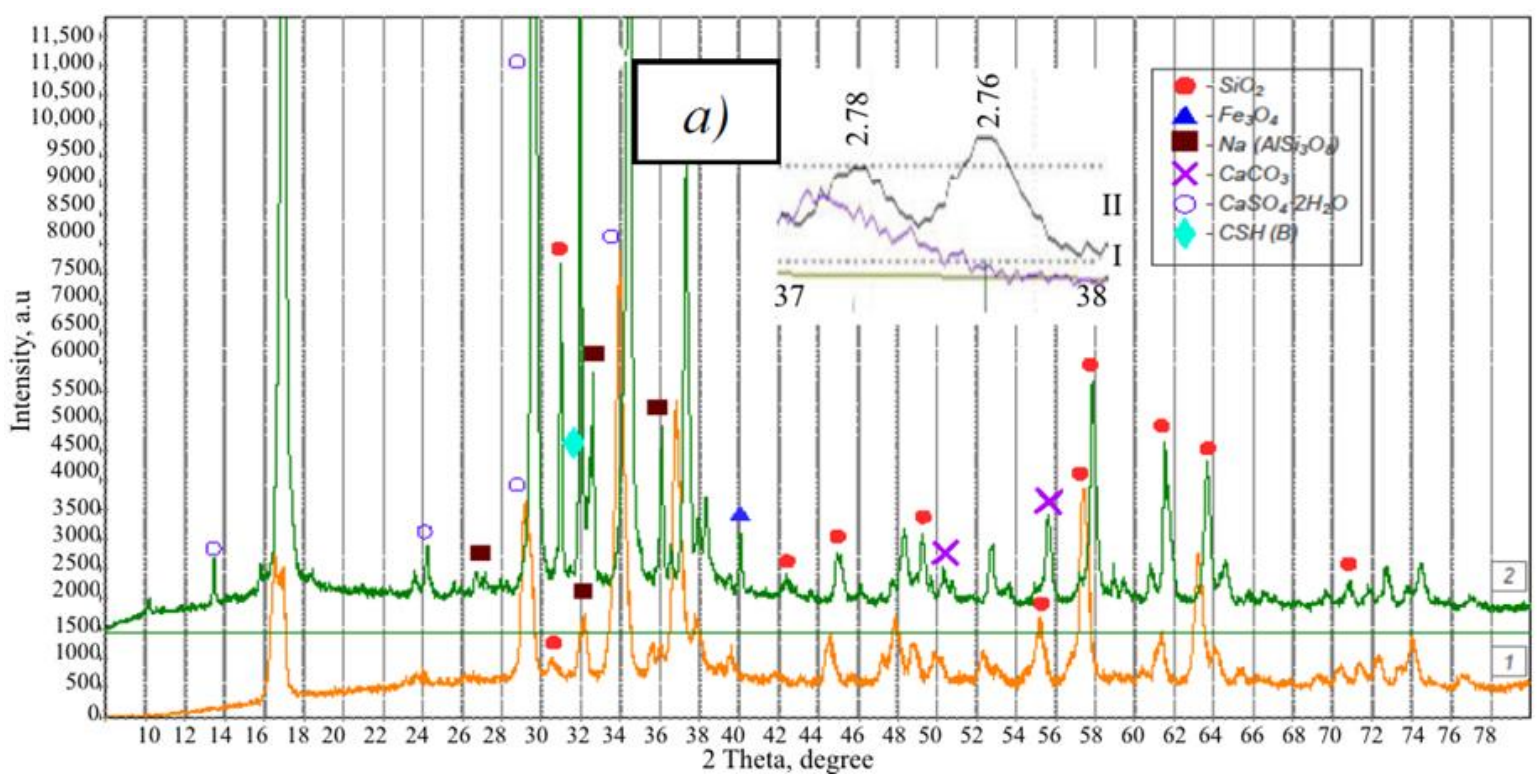

Figure 7. XRD patterns of the GCB-FA (1) and GCB-S (2); $a$-comparison of the profiles of the main interplanar distances of alite and belite in the GCB-FA (I) and GCB-S (II).

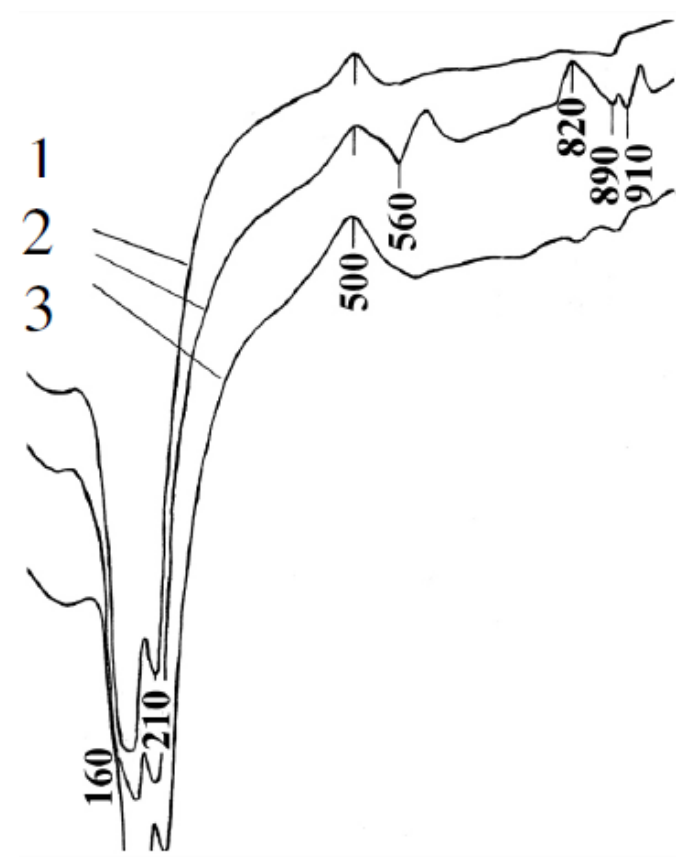

Figure 8. Results of the differential thermal analysis of the developed GCB at the age of 28 days. 1-GCB; 2-GCB-FA; 3-GCB-S. Three-digit numbers represent degrees Celsius.

Because of this, there is no fundamental difference between the GCB with fly ash and the GCB with slag, further studies of micro reinforcement are given for gypsum-cement binders with fly ash.

\subsection{Micro Reinforcement}

Table 8 lists the results of a study of mortars of a gypsum-cement fiber-reinforced composite (GCFRC).

It was found that the introduction of both polyamide and basalt fibers in the composition of the GCB-FA mix does not affect the setting time, but reduces its slump flow, because some of the mixing water is absorbed by the fiber. Therefore, it is recommended to introduce fibers into the quick-hardening mixture in a moistened state with continuous mixing (Figure 9). 
Table 8. Effect of microfiber on the properties of the hardened GCB-FA.

\begin{tabular}{ccccc}
\hline \multicolumn{2}{c}{ Fibers, \% } & \multirow{2}{*}{ Slump Flow, mm } & \multicolumn{2}{c}{ Setting Time, min-s } \\
\cline { 1 - 1 } Polyamid & Basalt & & Start & End \\
\hline- & - & 140 & $5-00$ & $8-30$ \\
1 & - & 100 & $5-00$ & $8-30$ \\
3 & - & 90 & $5-00$ & $8-30$ \\
5 & - & 75 & $5-00$ & $8-30$ \\
- & 1 & 120 & $5-00$ & $8-30$ \\
- & 3 & 110 & $5-00$ & $8-30$ \\
\hline
\end{tabular}

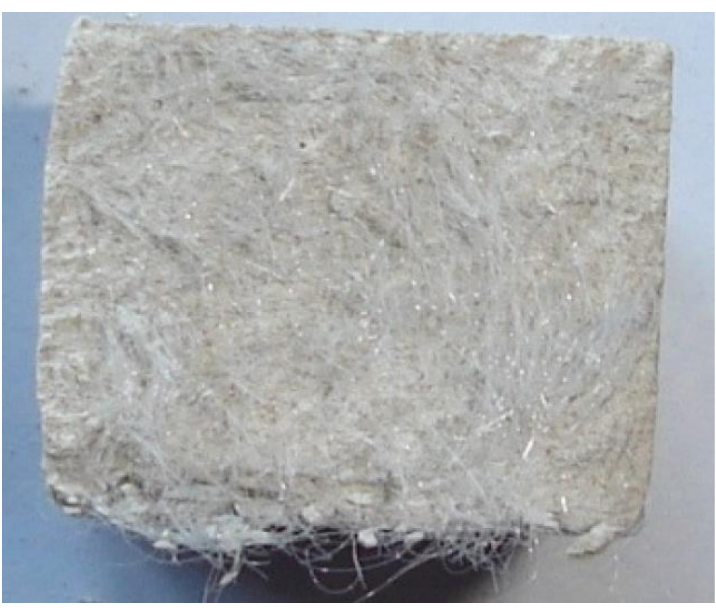

(a)

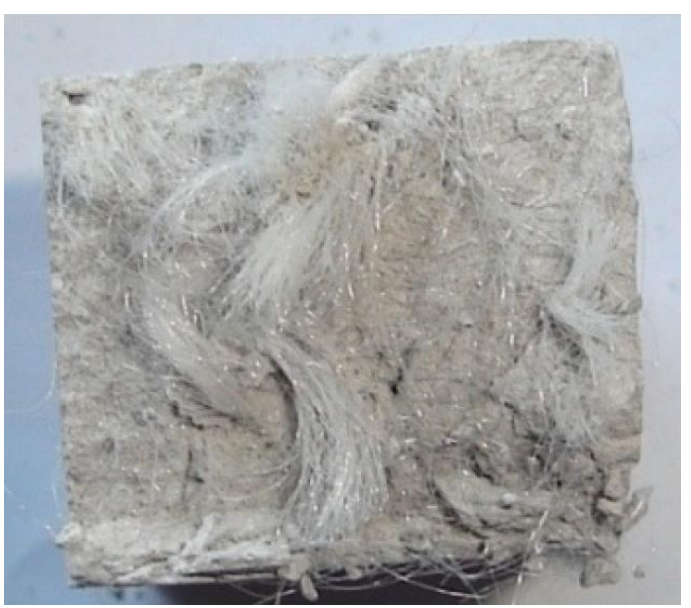

(b)

Figure 9. Uniform (a) and uneven (b) distribution of polyamide fiber in hardened GCB-FA specimens.

It was found that the introduction of polyamide fiber in an amount of up to $3 \%$ is effective. As a result of this, the flexural strength at the age of 7 days is increased by $16 \%$, at 28 days by $12 \%$. Table 9 lists the physicomechanical characteristics of the GCFRC.

Table 9. Physicomechanical characteristics of the gypsum-cement fiber-reinforced composite (GCFRC).

\begin{tabular}{|c|c|c|c|c|c|c|c|c|c|}
\hline \multicolumn{2}{|c|}{ Fibers, $\%$} & \multirow{2}{*}{$\begin{array}{l}\text { Density, } \\
\mathrm{kg} / \mathrm{m}^{3}\end{array}$} & \multicolumn{2}{|c|}{ Flexural Strength, MPa } & \multicolumn{4}{|c|}{ Compressive Strength, $\mathrm{MPa}$} & \multirow{2}{*}{$\begin{array}{c}\text { Softening } \\
\text { Coefficient, } \%\end{array}$} \\
\hline Polyamid & Basalt & & 7 Days & 28 Days & 2 Days & 7 Days & 28 Days & Dried & \\
\hline- & - & 1170 & 6.2 & 7.8 & 4.9 & 15.6 & 18.0 & 20.0 & 0.74 \\
\hline 3 & - & 1370 & 7.2 & 8.7 & 5.4 & 19.2 & 19.8 & 23.8 & 0.83 \\
\hline 5 & - & 1550 & 6.7 & 8.3 & 5.0 & 15.7 & 18.3 & 20.2 & 0.83 \\
\hline- & 1 & 1340 & 6.8 & 8.6 & 5.6 & 17.8 & 19.5 & 21.5 & 0.84 \\
\hline
\end{tabular}

With a further increase in the amount of polyamide fiber, $\mathrm{CaSO}_{4} \cdot 2 \mathrm{H}_{2} \mathrm{O}$ crystals are formed on their surface, which have insufficient adhesion to polyamide fibers, and no increase in strength was observed.

When basalt fibers are introduced into the GCB-FA, an aggressive medium is formed that destroys their surface with the formation of shells, which increases the adhesion strength of the hardened GCB and basalt fiber and, as a result, the strength of the composite itself. At the age of 7 days, the flexural strength increases by $19 \%$, at the age of 28 days-by $14 \%$, the softening coefficient increases by $17 \%$, with an increase in the durability of the structure. According to the results of the XRD shown in Figure 10 , as the hydration products in the samples, there is calcium bicarbonate $(\mathrm{d}=7.69 ; 4.30 ; 3.81$; $3.07 ; 2.88 \mathrm{~A})$; partially crystallized tobermorite-like calcium hydrosilicate $(\mathrm{d}=4.9 ; 3.07 ; 2.88 ; 2.79 ; 2.42$; $1.99 ; 1.81 \mathrm{~A})$; calcium carbonate $(\mathrm{d}=2.5 ; 2.49 ; 2.29 ; 2.09 ; 1.9 \mathrm{~A})$; portlandite $(\mathrm{d}=1.78,1.67 \mathrm{~A})$; low basic calcium hydroaluminates $(\mathrm{d}=3.35,2.29,2.22 \mathrm{~A})$. 


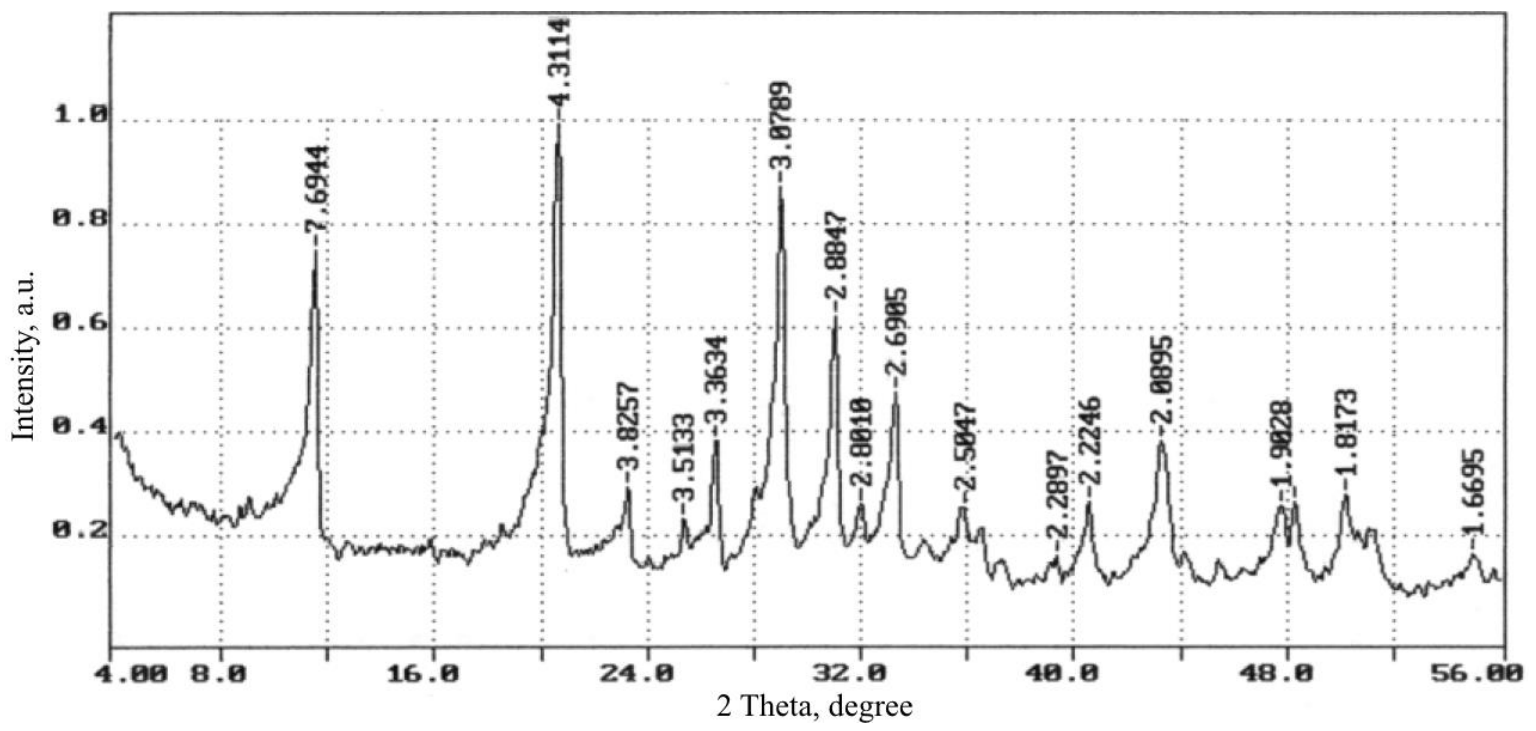

Figure 10. XRD pattern of the hardened GCB-FA. Identical for both types of fiber.

Thus, micro-reinforcing polyamide and basalt fibers are a kind of substrate on which a strong and dense layer of interfacial transition zone is formed. This layer has a rather large effect on the properties of the obtained quick-hardening material with sufficient saturation of the mix with fibers.

\section{Conclusions}

For the first time, scientific data on the properties of gypsum-cement fiber-reinforced composite using TPPW and microfiber have been obtained. Based on the results of various tests, the following conclusions were drawn:

1. The classification of raw materials for the production of the gypsum-cement binders has been developed taking into account their genesis.

2. The scientific basis for improving the production of water-resistant gypsum composite materials has been supplemented. They consist of the use of semi-aquatic gypsum, Portland cement, and technogenic thermal power plant waste with the grinding of all components.

3. The positive effect of the mechanical activation of the gypsum-cement binder components on the character of particle size distribution has been established. Compared to Portland cement, the GCB has a higher content of fine fractions. Accordingly, when they are used together, small gaps fill the gaps between large ones, compacting, and strengthening the composite structure.

4. The nature of the influence of technogenic silica-containing components on the structure formation of the system "gypsum-cement-superplasticizer-water" has been researched. It consists in the formation of a more dense composite structure due to the synthesis of low-basic calcium hydrosilicates and calcium hydroaluminates in a gypsum matrix. This leads to an increase in the strength, water resistance, and durability of the hardened matrix.

5. It has been established that the addition of polyamide or basalt fibers in the amount of 1-3\% into the GCB promotes an increase in flexural strength, water resistance, and a decrease in shrinkage microcracks with an increase in the durability of the structure of the gypsum-cement fiber-reinforced composite.

6. This study is an integral part of large-scale research on the development and use of GCB, conducted by the authors in recent years. The results of previous studies have applications as dry fast-setting mixtures for various construction applications, namely, for the construction of road bases, plumbing cabins, wall products.

7. It would be good to create a future database of results that can be used for more in-depth analysis using artificial intelligence (e.g., artificial neural networks). 
Author Contributions: Conceptualization, V.L. and R.F.; Data curation, N.C.; Funding acquisition, V.L.; Investigation, N.C.; Methodology, N.C.; Project administration, R.F.; Resources, N.V.; Software, V.L.; Supervision, N.V.; Validation, N.V.; Writing—original draft, R.F.; Writing—review \& editing, V.L. and N.V. All authors have read and agreed to the published version of the manuscript.

Funding: This work was financially supported by two RFBR grants: 1. No. 18-29-24113 “Transdisciplinarity-as a theoretical basis for the rational use of technogenic raw materials for energy-efficient technologies for the production of new generation building composites". 2. No. 18-03-00352 "Technogenic metasomatism in building materials science-as the basis for the design of future composites." The APC was funded by Peter the Great St. Petersburg Polytechnic University.

Conflicts of Interest: The authors declare no conflict of interest.

\section{References}

1. Mihai, T.; Iordache, V. Determining the indoor environment quality for an educational building. Energy Procedia 2016, 85, 566-574. [CrossRef]

2. Feduik, R.S.; Smoliakov, A.K.; Timokhin, R.A.; Batarshin, V.O.; Yevdokimova, Y.G. Using thermal power plants waste for building materials. IOP Conf. Ser. Earth Environ. Sci. 2017, 87, 92010. [CrossRef]

3. Evelson, L.; Lukuttsova, N. Application of statistical and multi fractalmodels for parameters optimization of nano-modified concrete. Int. J. Appl. Eng. Res. 2015, 10, 12363-12370.

4. Pacheco-Torgal, F.; Jalali, S. Cementitious building materials reinforced with vegetable fibres: A review. Constr. Build. Mater. 2011, 25, 575-581. [CrossRef]

5. Fediuk, R.S.; Lesovik, V.S.; Svintsov, A.P.; Mochalov, A.V.; Kulichkov, S.V.; Stoyushko, N.Y.; Gladkova, N.A.; Timokhin, R.A. Self-compacting concrete using pretreatmented rice husk ash. Mag. Civ. Eng. 2018, 79, 66. [CrossRef]

6. Klyuev, S.V.; Shevchenko, A.V.; Shorstova, E. Fiber concrete for 3-D additive technologies. Mater. Sci. Forum 2019, 974, 367-372. [CrossRef]

7. Fediuk, R.; Smoliakov, A.; Muraviov, A. Mechanical properties of fiber-reinforced concrete using composite binders. Adv. Mater. Sci. Eng. 2017, 2017, 2316347. [CrossRef]

8. Martins, C.; Santos, P.G.; Almeida, P.L.; Godinho, L.; Dias, A. Acoustic performance of timber and timber-concrete floors. Constr. Build. Mater. 2015, 101, 684-691. [CrossRef]

9. Charola, A.E.; Pühringer, J.; Steiger, M. Gypsum: A review of its role in the deterioration of building materials. Environ. Earth Sci. 2006, 52, 339-352. [CrossRef]

10. Quennoz, A.; Scrivener, K. Hydration of C3A-gypsum systems. Cem. Concr. Res. 2012, 42, $1032-1041$. [CrossRef]

11. Rovero, L.; Galassi, S.; Misseri, G. Experimental and analytical investigation of bond behavior in glass fiber-reinforced composites based on gypsum and cement matrices. Compos. Part B Eng. 2020, 194, 108051. [CrossRef]

12. Feduik, R. Reducing permeability of fiber concrete using composite binders. Spec. Top. Rev. Porous Media. 2018, 9, 79-89. [CrossRef]

13. Fediuk, R.; Pak, A.; Kuzmin, D. Fine-grained concrete of composite binder. IOP Conf. Ser. Mater. Sci. Eng. 2017, 262, 12025. [CrossRef]

14. Jones, M.R.; Mccarthy, M.J.; Mccarthy, A. Moving fly ash utilisation in concrete forward: A UK perspective. In Proceedings of the 2003 International Ash Utilization Symposium, Wrocław, Poland, 20 October 2003; University Press of Kentucky: Lexington, KY, USA, 2003; pp. 20-22.

15. Senhadji, Y.; Siad, H.; Escadeillas, G.; Benosman, A.; Chihaoui, R.; Mouli, M.; Lachemi, M. Physical, mechanical and thermal properties of lightweight composite mortars containing recycled polyvinyl chloride. Constr. Build. Mater. 2019, 195, 198-207. [CrossRef]

16. Abirami, T.; Loganaganandan, M.; Murali, G.; Fediuk, R.; Sreekrishna, R.V.; Vignesh, T.; Januppriya, G.; Karthikeyan, K. Experimental research on impact response of novel steel fibrous concretes under falling mass impact. Constr. Build. Mater. 2019, 222, 447-457. [CrossRef]

17. Fediuk, R.; Smoliakov, A.; Stoyushko, N. Increase in composite binder activity. IOP Conf. Ser. Mater. Sci. Eng. 2016, 156, 012042. [CrossRef]

18. Loganina, V.I.; Ryzhov, A.D. Properties of limy composites with the addition aluminosilicates. Contemp. Eng. Sci. 2015, 8, 409-413. [CrossRef] 
19. Kuntze, R.A. Gypsum Board. Gypsum Connect. Sci. Technol 2010, 73, 73-101. [CrossRef]

20. Kolomatskaya, V.S.; Lesovik, A.; Kolomatskiy, A. Hydration processes during autoclaved aerated concrete structure formation. In Proceedings of the 5th International Conference on Autoclaved Aerated Concrete, Moscow, Russia, 15 May 2011.

21. Tian, B.; Cohen, M.D. Does gypsum formation during sulfate attack on concrete lead to expansion? Cem. Concr. Res. 2000, 30, 117-123. [CrossRef]

22. Klyuev, S.V.; Khezhev, T.A.; Pukharenko, Y.; Klyuev, A. Fiber Concrete on the basis of composite binder and technogenic raw materials. Mater. Sci. Forum 2018, 931, 603-607. [CrossRef]

23. Gardner, N.J.; Lockman, M.J. Design provisions for drying shrinkage and creep of normal-strength concrete. ACI Mater. J. 2001, 98, 159-167. [CrossRef]

24. Juenger, M.; Winnefeld, F.; Provis, J.L.; Ideker, J.H. Advances in alternative cementitious binders. Cem. Concr. Res. 2011, 41, 1232-1243. [CrossRef]

25. Michel, M.; Georgin, J.; Ambroise, J.; Pera, J. The influence of gypsum ratio on the mechanical performance of slag cement accelerated by calcium sulfoaluminate cement. Constr. Build. Mater. 2011, 25, 1298-1304. [CrossRef]

26. Jones, M.R.; McCarthy, A. Behaviour and assessment of foamed concrete for construction applications. In Proceedings of the International Conference on the Use of Foamed Concrete in Construction, Dundee, UK, 10 August 2005.

27. Markin, V.; Nerella, V.N.; Schröfl, C.; Guseynova, G.; Mechtcherine, V. Material design and performance evaluation of foam concrete for digital fabrication. Materials 2019, 12, 2433. [CrossRef]

28. Butakova, M.; Gorbunov, S. Study of the influence of complex additives on properties of the gypsum-cement-puzzolan binder and concretes on its basis. Procedia Eng. 2016, 150, 1461-1467. [CrossRef]

29. Jones, M.; McCarthy, A.; Jones, M.R. Utilising unprocessed low-lime coal fly ash in foamed concrete. Fuel 2005, 84, 1398-1409. [CrossRef]

30. Mosaberpanah, M.A.; Eren, O. $\mathrm{CO}_{2}$-full factorial optimization of an ultra-high performance concrete mix design. Eur. J. Environ. Civ. Eng. 2016, 22, 450-463. [CrossRef]

31. Boon, K.H.; Loon, L.Y.; Chuan, D.Y.E. Compressive strength and shrinkage of foamed. Concrete 2006, 12, 1-8.

32. Roslan, A.F.; Awang, H.; Mydin, M.A.O. Effects of various additives on drying shrinkage, compressive and flexural strength of lightweight foamed concrete (LFC). Adv. Mater. Res. 2012, 626, 594-604. [CrossRef] 